\title{
FINITE ELEMENT ANALYSIS OF MAXILLARY CENTRAL INCISORS RESTORED WITH VARIOUS POST-AND-CORE APPLICATIONS
}

\author{
MinSeock Seo', WonJun Shon', WooCheol Lee', Hyun-Mi Yoo², Byeong-Hoon Cho', Seung-Ho Baek' \\ ${ }^{\prime}$ Department of Conservative Dentistry and Dental Research Institute, School of Dentistry, Seoul National University \\ ${ }^{2}$ Department of Conservative Dentistry, The Institute of Oral Health Science, Samsung Medical Center, \\ Sungkyunkwan University School of Medicine
}

\begin{abstract}
The purpose of this study was to investigate the effect of rigidity of post core systems on stress distribution by the theoretical technique, finite element stress-analysis method. Three-dimensional finite element models simulating an endodontically treated maxillary central incisor restored with a zirconia ceramic crown were prepared and $1.5 \mathrm{~mm}$ ferrule height was provided. Each model contained cortical bone, trabecular bone, periodontal ligament, $4 \mathrm{~mm}$ apical root canal filling, and post-and-core. Six combinations of three parallel type post (zirconia ceramic, glass fiber, and stainless steel) and two core (Paracore and Tetric ceram) materials were evaluated, respectively. A $50 \mathrm{~N}$ static occlusal load was applied to the palatal surface of the crown with a $60^{\circ}$ angle to the long axis of the tooth. The differences in stress transfer characteristics of the models were analyzed. von Mises stresses were chosen for presentation of results and maximum displacement and hydrostatic pressure were also calculated. An increase of the elastic modulus of the post material increased the stress, but shifted the maximum stress location from the dentin surface to the post material. Buccal side of cervical region (junction of core and crown) of the glass fiber post restored tooth was subjected to the highest stress concentration. Maximum von Mises stress in the remaining radicular tooth structure for low elastic modulus resin core (29.21 MPa) was slightly higher than that for high elastic modulus resin core (29.14 MPa) in case of glass fiber post. Maximum displacement of glass fiber post restored tooth was higher than that of zirconia ceramic or stainless steel post restored tooth. [J Kor Acad Cons Dent 34(4):324-332, 2009]
\end{abstract}

Key words: Post and Core, Finite element analysis, Zirconia ceramic post, Glass fiber post

-Received 2009.4.16., revised 2009.5.31., accepted 2009.6.1.-

\section{I . Introduction}

Restoration of endodontically treated teeth is still a controversial subject in these days. It is known that those teeth are generally weakened because of dental structure loss, cavities, filling preparation and root canal instrumentation ${ }^{1)}$. Therefore, special care is indicated when selecting the most efficient way to restore them.

* Corresponding author: Seung-Ho Baek

Department of Conservative Dentistry, School of dentistry, Seoul National University

275-1 Yengeon-Dong, Jongno-Gu, Seoul, 110-768, Korea

Tel: 82-2-2072-3951 Fax: 82-2-2072-3859

E-mail: shbaek@snu.ac.kr
It is believed that when an endodontically treated tooth is subjected to occlusal loads, stress is mostly concentrated at the cervical area ${ }^{2}$. The placement of posts in endodontically treated teeth reduced stress in this area ${ }^{3-5)}$. When the post is inserted into the root canal, some of its force is directed along the post length. Thus, the placement of posts may assist in protecting the remaining tooth structures ${ }^{6}$. In the case of substantial horizontal loss of the clinical crown, there is no restorative alternative other than fabricating a post-and-core buildup. Nowadays, prefabricated posts are more preferred than custommade posts in many cases and many materials have been developed for prefabricated post. Titanium, 
glass fiber reinforced polymer, and ceramic posts currently predominate, because their performance can be compared with that of custom-made posts ${ }^{7}$.

The fracture resistance of dowel-restored teeth has been the subject of numerous in vitro and in vivo studies with a theoretical approach. Many contradictory points of view regarding the best choice of dowel and restorative technique can be found in the literature. One reason for this contradiction is that in vivo studies often cannot control the many variables that are present clinically. Another reason is that in vitro studies on fracture resistance are encumbered with standard deviations that are relatively very high. Because of the large variability of the results obtained from in vitro studies, an increasing number of investigations of dowel-restored teeth are based on finite element analysis ${ }^{8-11)}$

Although photo-elastic analysis supplies visual information on stress distribution, it is limited by the fact that it does not supply information on the state of single component of the sample (post, cement, root, etc.). An innovative method recently introduced to dentistry is finite element analysis in which the various component of a system are digitally modeled and subdivided into simpler geometric shapes or elements whose apices meet to form nodes. The elastic constants and E (Young's elastic modulus) and $\nu$ (Poisson's ratio) for the modeled materials are specified for each element. A system of simultaneous equations is generated and solved to yield predictable stress distributions in each element throughout a structure $^{12)}$.

Although finite element analysis doesn't permit any variation in interpreting results, considerable controversy exists regarding the optimal choice of material of dowel and core in previous finite element analysis studies. In one study, a root canal dowel of high modulus is recommended ${ }^{13)}$, while another advocates that a modulus of elasticity close to that of dentin is preferable ${ }^{8)}$. That is because the stress distribution patterns simulated may be different depending on the model used in the experiments. Therefore, study with more clinically relevant model is needed.

The purpose of this study was to investigate the effect of rigidity of post-and-core systems on stress distribution by finite element stress analysis method in moderately fractured maxillary central incisor model.

\section{II . Materials and Methods}

The study was conducted using a three-dimensional FE method (FEM) and FE structural analysis programs were HyperVeiw 8.0 (Hyperwork, Altair, Korea) and ABAQUS 6.5 (ABAQUS Inc, Providence, RI).

A three dimensional FE model was fabricated to represent an endodontically treated maxillary central incisor. The model contained a simulated periodontal ligament (PDL) and alveolar bone structure (Figure 1). The external shape of the maxillary central incisor was obtained by the micro CT (SkyScan 1072, SkyScan N.V., Belgium) of a previously extracted maxillary central incisor. The scanned profiles were assembled in a 3D wire frame structure using 3D image software (V-works 4.0, Cybermed Inc. Korea). On the basis of the root-form geometry of teeth, a simplified $0.25 \mathrm{~mm}$ PDL and $0.25 \mathrm{~mm}$ lamina dura were developed. The cortical layer of bone was $2 \mathrm{~mm}$ thick and was covered with $1 \mathrm{~mm}$ thick layer of soft tissue. The remaining bone was modeled as trabecular bone.

Tooth length was $21 \mathrm{~mm}$ long and incisal $7 \mathrm{~mm}$ was supposed to be fractured horizontally and $1.5 \mathrm{~mm}$ ferrule height was modeled(Figure 2). $12 \mathrm{~mm}$ parallel type post was inserted and width of post was $1.4 \mathrm{~mm}$. Gutta-percha filling was left $4 \mathrm{~mm}$ apically and core height was $6.5 \mathrm{~mm}$. The crown and post were retained with a resin luting cement of thickness of $0.1 \mathrm{~mm}$.

In the FE analysis, three different post materials and two different core materials were evaluated, respectively (Table 2). The post systems modeled for analysis were a glass fiber, stainless steel and zirconia ceramic post material. The core materials modeled were Tetric Ceram (Ivoclar Vivadent, Schaan, Liechtenstein) and Paracore (Coltene Whaledent, Langenau, Germany) composite resins. A zirconia ceramic (Zirconia LAVA , 3M ESPE, USA) was simulated as the final crown material.

An average occlusal force of $50 \mathrm{~N}$ was determined from the literature ${ }^{14)}$ (Figure 3). Static occlusal load was applied on the palatal surface of the crown at a 60 
degree angle to the tooth' s longitudinal axis. Nodes at basis of the alveolar bone were assumed as fixed in all directions to calculate the stress distribution.

The mathematical models included 13616 nodes and 67437 tetrahedral solid elements. Except for the glass fiber post, materials used in study were assumed as homogeneous and isotropic. The glass fiber post was considered orthotropic, so that it showed different mechanical properties along the fiber direction ( $\mathrm{x}$-direction) and along the other two normal directions ( $y-$ and $z^{-}$-direction) $)^{15}$. The elastic properties of the materials (Young's modulus[E] and Poisson's ratio $[\mu]$ ) were determined from the literatures and are provided in Table 1.

The FEM results are presented as stresses distributed in the investigated structures. These stresses may occur as tensile, compressive, shear, or a stress combination known as equivalent von Mises stresses. von Mises stresses depend on the entire stress field and are a widely used indicator of the possibility of damage occurrence ${ }^{10,16)}$. Thus, von Mises stresses were chosen for presentation of results, and maximum displacement and hydrostatic pressure were also calculated.

Table 1. Mechanical properties of investigated materials

\begin{tabular}{|c|c|c|c|}
\hline Material & $\begin{array}{c}\text { Elastic modulus } \\
\qquad(\mathrm{E} ; \mathrm{GPa})\end{array}$ & $\begin{array}{l}\text { Poisson's } \\
\text { ratio }(\nu)\end{array}$ & $\begin{array}{l}\text { Ref } \\
\text { No. }\end{array}$ \\
\hline Dentin & 18.6 & 0.31 & 9 \\
\hline Periodontal ligament & 0.0689 & 0.45 & 9 \\
\hline Cortical bone & 13.7 & 0.30 & 9 \\
\hline Trabecular bone & 1.37 & 0.30 & 9 \\
\hline Gutta-percha & 0.00069 & 0.45 & 9 \\
\hline Zirconia ceramic post & 200 & 0.23 & 27 \\
\hline Tetric Ceram ${ }^{a}$ & 9.4 & 0.28 & \\
\hline Paracore $^{\text {a }}$ & 20 & 0.30 & \\
\hline Stainless steel post & 207 & 0.30 & 30 \\
\hline Zirconia ceramic (LAVA) & 210 & 0.23 & \\
\hline Resin luting cement & 8.0 & 0.30 & 11 \\
\hline Gingiva & 0.003 & 0.45 & 11 \\
\hline \multirow[t]{3}{*}{ Glass fiber post } & Ex 37 & $v_{\text {xy }} \quad 0.27$ & 27 \\
\hline & Ey $\quad 9.5$ & 0.34 & \\
\hline & Ez $\quad 9.5$ & 0.27 & \\
\hline
\end{tabular}

${ }^{a}$ Acquired from manufacturer

\section{Results}

Stress values are present in all of the structures as color figures in Figure 4 and hydrostatic pressure values are present in Figure 5. Both stress values and its location were different between the 3 evaluated types of post systems. High stress values were observed in the buccal portion of the post in Model 1, 3 particularly, at the middle third of the post. Low stress values were observed at the apical and coronal tip of the post.

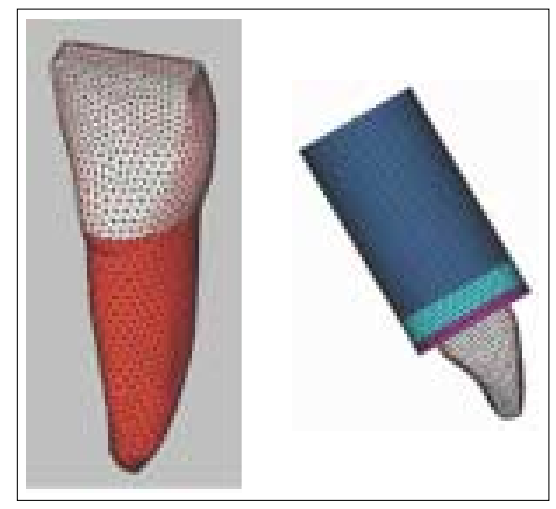

Figure 1. 3-D finite element model of Maxillary central incisor.

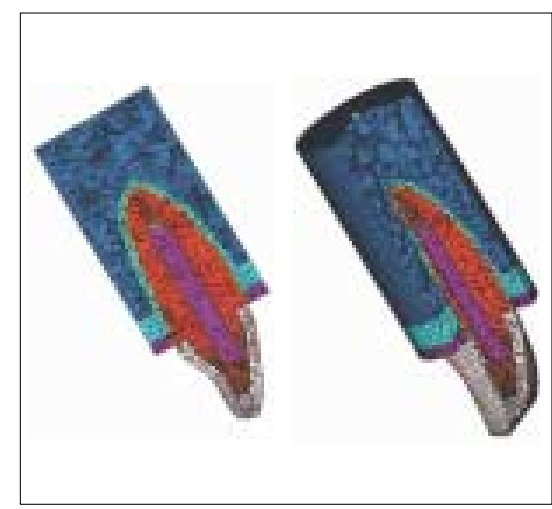

Figure 2. Illumination of ferrule height and post space

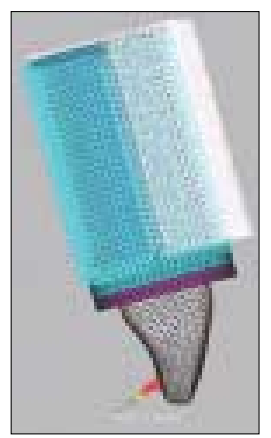

Figure 3. Load application. 
In Model 2 and 5, stress concentrated on the buccal side of the CEJ next to the prosthetic margin and progressively decreased from the outer to the inner portion of the root. In Model 4, 6, stress distributions quite similar to those described for Model 1,3 were observed. When the zirconia ceramic post and glass fiber post system were compared, von Mises stresses were smaller for glass fiber post system (Table 2).

In Model 1,3,4,6, both compressive force and tensile force were concentrated primarily on zirconia ceramic or stainless steel post. In Model 2,5, however, compressive force was concentrated on the buccal side of coronal root portion and tensile force was on the lingual side of coronal root portion.

In Model 2, the maximum von Mises stress was slightly greater than that of Model 5 . In case of glass fiber post, Paracore core (29.14 MPa) exhibited slightly less stress concentration in dentin when compared with Tetric Ceram core (29.21 MPa). Maximum displacement of glass fiber post restored a

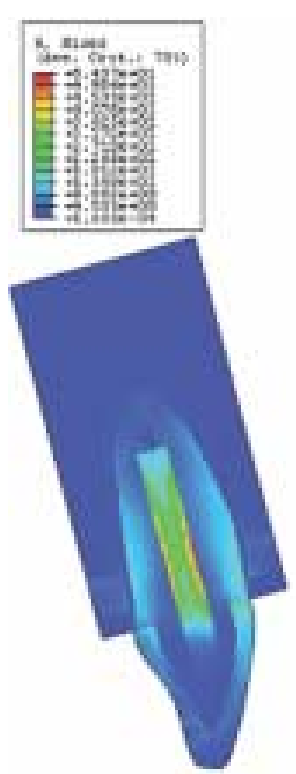

d

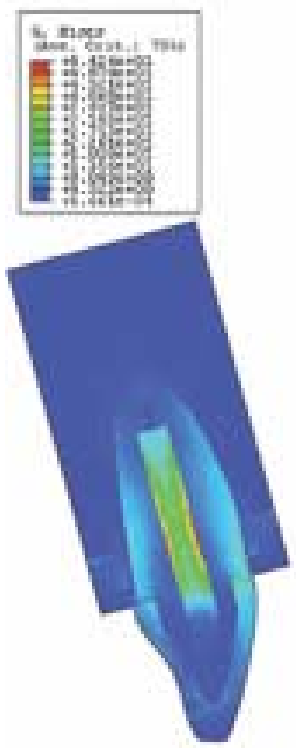

b
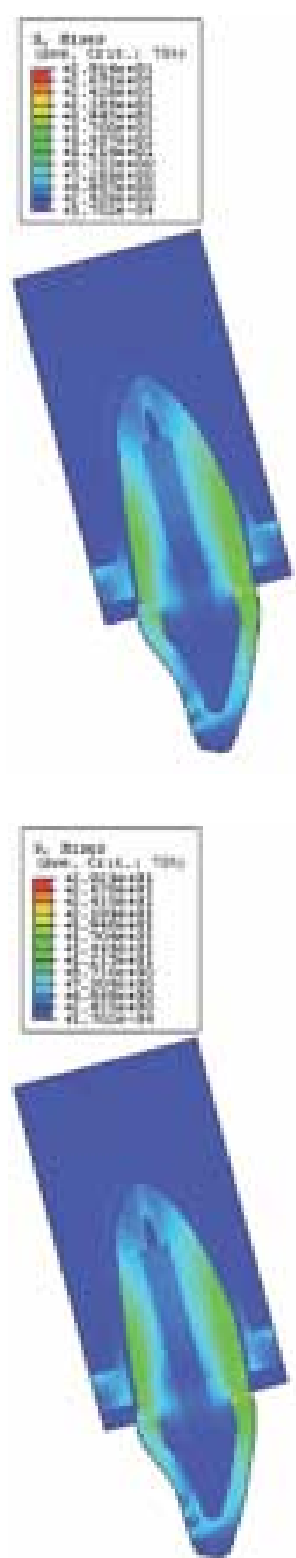

c
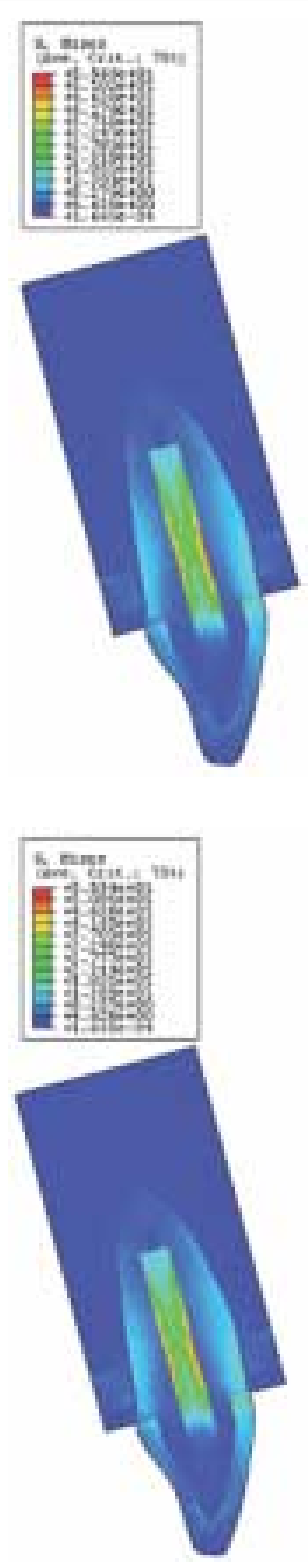

Figure 4. Distribution of von Mises stresses (MPa) in bucco-lingual section. a. Model 1, b. Model 2, and c. Model 3, d. Model 4, e. Model 5, and f. Model 6. Dark blue to red colors represent stress values from lower to higher, respectively 
Table 2. Maximum von Mises stress and maximum displacement of experimental models.

\begin{tabular}{ccccc}
\hline Model & Core & Post & Max. von-Mises stress (MPa) & Max. Displacement $(\mathrm{mm})$ \\
\hline 1 & Paracore & Zirconia ceramic & 54.37 & 0.03250 \\
2 & Paracore & Glass fiber & 29.14 & 0.03497 \\
3 & Paracore & Stainless steel & 55.66 & 0.03245 \\
4 & Tetric Ceram & Zirconia ceramic & 54.26 & 0.03252 \\
5 & Tetric Ceram & Glass fiber & 29.21 & 0.03499 \\
6 & Tetric Ceram & Stainless steel & 55.54 & 0.03247 \\
\hline
\end{tabular}

a
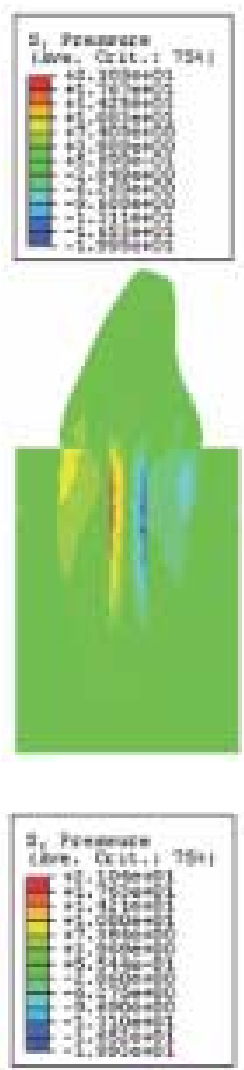

d

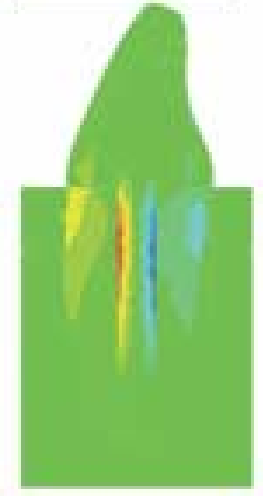

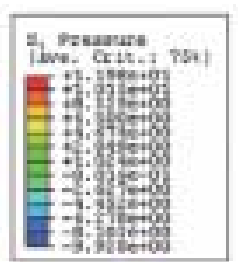

b
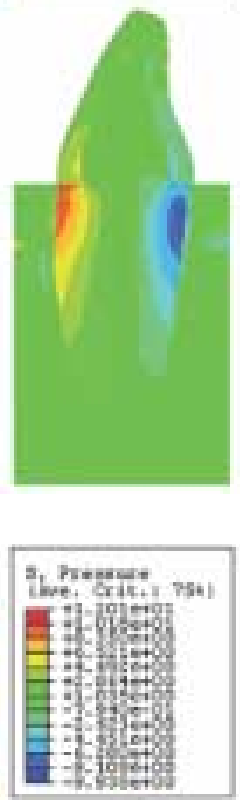

$\mathbf{e}$

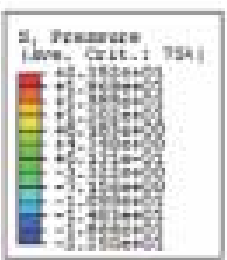

C
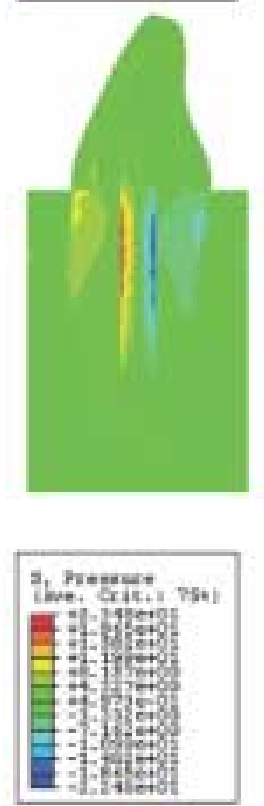

f

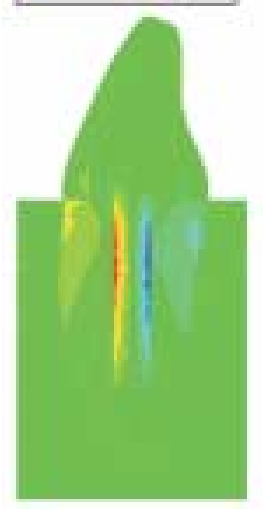

Figure 5. Distribution of hydrostatic pressure (MPa) in bucco-lingual section. a Model 1, b Model 2, and c Model 3, d Model 4, e Model 5, and f Model 6. The blue color indicates the area is under tensile force and the red color indicates the area is under compressive force. 
tooth $(0.03497-0.03499)$ was higher than that of zirconia ceramic or stainless steel post restored tooth (0.03245-0.03452 mm).

\section{Discussion}

The FEM has been used in many previous investigations of the stresses generated in post-and-core restored teeth and has been shown to be a useful tool when investigating complex systems that are difficult to standardize in vitro and in vivo $0^{10,11.17)}$.

The FEM has several limitations. The accuracy of a 3-D FEM relies on the precision of the simulation model. However, the physical properties of biologic structures are only approximates, since all materials are considered homogeneous and have a linear response to stress. Actually, in a living organism, the response to these structures to stress is more complex, For instance, it is well described that cortical bone of the mandible is transversely isotropic and inhomogeneous ${ }^{18)}$. In addition, the stress distribution patterns simulated may be different depending on the materials and properties assigned to each layer of the model and the model used in the experiments ${ }^{19,20)}$. Thus, the inherent limitations in this study should be considered.

Sorensen et al ${ }^{211}$ reported that coronal dentin above the shoulder decreased stress concentration in dentin, so, in the modeling process of this study, a ferrule design was created in the proximal, lingual and buccal surfaces at the cervical region. Pierrisnard et al. ${ }^{16)}$ reported that ferrule preparation was more efficient when the post has a high elastic modulus. The combination of a tooth-colored core and restorative material was chosen, considering that a zirconia ceramic crown should restore an endodontically treated tooth for optimum esthetic results.

Stress concentrates where not homogeneous material distributions are present just like interfaces. Interfaces of materials with different moduli of elas ${ }^{-}$ ticity represent the weak link of restorative systems ${ }^{5222}$. Stresses located at the dentin may influence the risk of root fracture, and stresses located at post/dentin interface may influence the risk of loss of post retention. Thus, every effort should be made to reduce these stresses. The present study compared the stress distributions of different restorative systems to identify areas of high stress concentration, where eventual fatigues are more expected to occur.

Boschien et al. ${ }^{12)}$ emphasized the effect of elastic modulus of the post material on stress transferred to tooth structures. They reported that post material that has higher elastic modulus than dentin is capable of causing dangerous and non-homogeneous stresses in root dentin. That study concluded that when fiber posts are used for restoration, the integrity of the root, post, and core unit can be best preserved. In other aspect, Asmussen et al. ${ }^{17)}$ found that increasing the elastic modulus of the post caused decreased dentin stress. and this result was in agreement with an earlier in vitro investigation of the resistance of post-and-core restored teeth to cyclic loading ${ }^{21)}$ and with a theoretical study using $\mathrm{FEM}^{24)}$. The result of this study was in agreement with authors who were mentioned above. Maximum von Mises stresses of zirconia ceramic and stainless steel post group were significantly higher than glass fiber post group and the stress was more homogeneously distributed around the glass fiber post than zirconia ceramic and stainless steel post. Also, dentin stresses of zirconia ceramic and stainless steel post group were lower than that of glass fiber post group.

When the 3-D models of maxillary central incisors were subjected to simulated masticatory loading, the maximum von Mises stress in dentin was concentrated on the coronal third of the buccal surface of the root. When the zirconia ceramic crown was luted on composite core, the zirconia ceramic produced a stress shielding effect on the core materials: as a consequence, deformations concentrated on root dentin next to the prosthetic crown interface. However, when a relatively rigid material just like zirconia ceramic was used to build a prosthetic crown, the material properties of the more elastic composite materials did not significantly influence the stress concentrations within the core.

In this results, high stress values were observed at the post materials with the zirconia ceramic and stainless steel post system. It is known that, when force is applied to composite or layered materials, stress tend to maximize within the material with the highest elastic modulus. Therefore, the stresses were more concen- 
trated in the post of the zirconia ceramic and stainless steel post models, as it has a higher elastic modulus than other structures. This finding was in agreement with the study by Eskitascioglu et al. ${ }^{11}$

This study demonstrated that zirconia ceramic post more resisted bending forces than glass fiber post due to a higher modulus of elasticity. As a result, a zirconia ceramic post can stand heavier load than the latter. Consequently, stresses acting on the dentin decrease. This finding in this study is in accordance with a study reported by Ho et al. ${ }^{25}$. Due to the high modulus of elasticity of zirconia ceramic, forces were transmitted directly to the post/tooth interface without stress absorption ${ }^{26)}$. This may lead to a decrease in fracture resistance of the tooth. Also, glass fiber post may demonstrate deformation under simulated masticatory loadings. This may result in greater stress concentration in dentin and may lead to fracture.

In this study, maximum von Mises stress in the remaining radicular tooth structure for low elastic modulus resin core was slightly higher than that for high elastic modulus resin core in case of glass fiber post. Core with lower elastic modulus transferred higher deformations to the glass post, increasing the material properties discontinuity and producing higher stress values. Conversely, core with higher elastic modulus reduced the strain of the glass fiber post and decreased the mechanical properties mismatch, leading to lower stress arising. If the modulus of elasticity of the core material is similar to the post material, a more uniform stress distribution within the entire post-and-core restoration and within dentin is achieved, while the restoration' s resistance is increased against the high forces of mastication $^{27.28)}$.

As with many in vitro studies, it is difficult to extrapolate the results of this study directly to a clinical situation ${ }^{29}$. For example, the finish line and ferrule were placed at a constant height around the periphery of the teeth. Clinically, that is extremely difficult to be achieved. Further studies that better simulate the oral environment and including fatigue loading are recommended.

\section{Conclusions}

In FEM, assumptions related to material properties of simulated structures are not usually absolute representations of the structure. In reality, the structures modeled are much more dynamic. Within the limitations of this theoretical study, the following conclusions were drawn:

1. An increase of the elastic modulus of the post material increased the stress, but shifted the maximum stress location from the dentin surface to the post material.

2. Buccal side of cervical region (junction of core and crown) of the glass fiber post restored tooth was subjected to the highest stress concentration

3. Maximum von Mises stress in the remaining radicular tooth structure for low elastic modulus resin core was slightly higher than that for high elastic modulus resin core in case of glass fiber post.

4. Maximum displacement of glass fiber post restored tooth was higher than that of zirconia ceramic or stainless steel post restored tooth.

\section{References}

1. Albuquerque RC, Polleto LT, Fontana RH, Cimini CA. Stress analysis of an upper central incisor restored with different posts. J Oral Rehabil 30: 936-943, 2003

2. Hunter AJ, Feiglin B, Williams JF. Effects of post placement on endodontically treated teeth. $J$ Prosthet Dent 62:166-172, 1989

3. Ottl P. Hahn L, Lower HC, Fay M. Fracture characteristics of carbon fiber, ceramic and non-palladium endodontic post systems at monotonously increasing loads. J Oral Rehabil 29:175-182, 2002

4. Ko CC, Chu CS, Chung KH, Lee MC. Effects of posts on dentin stress distribution in pulpless teeth. $J$ Prosthet Dent 68:421-427, 1992

5. Assif D, Gorfil C. Biomechanical considerations in restoring endodontically treated teeth. $J$ Prosthet Dent 71:565-567, 1994

6. Caputo AA, Standlee JP. Biomechanics in Clinical Dentistry Chicago Quinte ssence Publishing Co, Inc 1987. p 185-203

7. Rosnetritt M, Furer C, Behr M, Lang R, Handel G. Comparison of in vitro fracture strength of metallic and tooth-coloured posts and cores. J Oral Rehabil 27:595601, 2000

8. Yaman SD, Alacam T, Yamen Y. Analysis of stress distribution in a maxillary central incisor subjected to various post and core applications. J Endod 24:107111,1998

9. Holmes DC, Diaz-Arnold AM, Leary JM. Influence of 
post dimension on stress distribution in dentin. $J$ Prosthet Dent 75:140-147, 1996

10. Pegoretti A, Fambri L, Zappini G, Bianchetti M. Finite element analysis of a glass fibre reinforced composite endodontic post. Biomaterials 23:2667-2682, 2002

11. Eskitascioglu G, Belli S, Kalkan M. Evaluation of two post core systems using two different methods (fracture strength test and a finite elemental stress analysis). J Endod 28:629-633, 2002

12. Boschian PL, Guidotti S, Pietrabissa R, Gandliani M. Stress distribution in a post-restored tooth using the three-dimensional finite element method. J Oral Rehabil 33:690-697, 2006

13. Manning KE, Yu DC, Yu KC, Kwan EW. Factors to consider for predictable post and core build-ups of endodontically treated teeth. Part II : clinical application of basic concepts. J Canad Dent Assoc 61:696707, 1995

14. Sorrentino R, Salameh Z, Apicella D, Auriemma T, Zarone F, Apicella A, Ferrari M. Three-dimensional finite element analysis of stress and strain distributions in post-and-core treated maxillary central incisors. J Adhes Dent 9:527-536, 2007

15. Sorrentino R, Aversa R, Ferro V, Auriemma T, Zarone F, Ferrari M, Apicella A. Three-dimensional finite element analysis of strain and stress distributions in endodontically treated maxillary central incisors restored with different post, core and crown materials. Dent Mater 23:983-993, 2007

16. Pierrisnard L, Bohin F, Renault P, Barquins M. Corono-radicular reconstruction of pulpless teeth: a mechanical study using finite element analysis. $J$ Prosthet Dent 88:442-448, 2002

17. Asmussen E, Peutzfeldt A, Sahafi A. Finite element analysis of stresses in endodontically treated, dowelrestored teeth. J Prosthet Dent 94: 321-329, 2005

18. Eskitascioglu G, Usumez A, Sevimay M, Soykan E, Unsal E. The influence of occlusal loading location on stresses transferred to implant- supported prostheses and supporting bone: A three-dimensional finite element study. J Prosthet Dent 91:144-150, 2004

19. Park JK, Hur B, Kim SK. The influence of combining composite resins with different elastic modulus on the stress distribution of class $V$ restoration: A threedimensional finite element study. J Kor Acad Cons
Dent 33:184-197, 2008

20. Park CS, Hur B, Kim KH, Son K, Park JK. The influence of occlusal load on stress distribution of cervical composite resin restorations: A three-diemnsional finite element study. J Kor Acad Cons Dent 33:246257, 2008

21. Sorensen JA, Engelman MJ. Ferrule design and fracture resistance of endodontically treated teeth. $J$ Prosthet Dent 63:529-536, 1990

22. Ausiello P, Gee AJ, Rengo S, Davidson CL. Fracture resistance of endodontically treated premolars adhesively restored. Am J Dent 10: 237-241, 1997

23. Sahafi A, Peutzfeldt A, Ravnholt G, Asmussen E, Gotfredsen K. Resistance to cyclic loading of teeth restored with posts. Clin Oral Investig 9:84-90, 2005

24. Eraslan O, Aykent F, Yucel MT, Akman S. Finite element analysis of the effect of ferrule height on stress distribution at post-and-core restored all-ceramic anterior crowns. Clin Oral Invest 2008;Aug 12. 〔Epub ahead of print]

25. Ho MH, Lee SY, Chen HH, Lee MC. Three-dimensional finite element analysis of the effects of posts on stress distribution in dentin. J Prosthet Dent 72:367372, 1994

26. Mannocci F, Ferrari M, Watson TF. Intermittent loading of teeth restored using quartz fiber, carbon-quartz fiber, and zirconium dioxide ceramic root canal posts. $J$ Adhes Dent 1:153-158, 1999

27. Asmussen E, Peutzfeldt A, Heitmann T. Stiffness, elastic limit, and strength of newer types of endodontic posts. J Dent 27:275-278, 1999

28. Toksavul S, Zor M, Toman M, Gunror MA, Nergiz I, Artunc C. Analysis of dentinal stress distribution of maxillary central incisors subjected to various postand-core applications. Oper Dent 31:89-96, 2006

29. Park JK, Hur B, Kim SK. Stress distribution of class V composite resin restorations: A three-dimensional finite element study. J Kor Acad Cons Dent 33:28-38, 2008

30. Barjau-Escribano A, Sancho-Bru JL, Forner-Navarro L, Rodriguez- Cervantes PJ, Perez-Gonzalez A, Sanchez-Marin FT. Influence of prefabricated post material on restored teeth: fracture strength and stress distribution. Oper Dent 31:47-54, 2006 


\title{
국문초록
}

\author{
여러가지 post-and-core로 수복된 상악 중절치의 유한요소법적 연구 \\ 서민석 ${ }^{1}$ 손원준 ${ }^{1} \cdot$ 이우철1 · 유현미 $\left.\right|^{2}$ 조병훈 ${ }^{1}$ 백승호 ${ }^{*}$ \\ ${ }^{1}$ 서울대학교 치의학대학원 치과보존학교실, ${ }^{2}$ 성균관대학교 의과대학 삼성서울병원 치과보존과
}

근관 치료된 치아의 수복에 있어서 파절은 가장 중요하게 고려되는 점이다. 포스트를 사용해서 수복한다는 것은 치수 와 다른 단단한 물질을 근관 내에 삽입한다는 것으로 자연스럽지 못한 구조를 만들어서 고유의 응력분산을 변화시킨다. 오랫동안 수많이 in vitro 연구들이 post-and-core로 수복된 치아의 파절 저항에 대해서 이루어졌지만 어떤 것이 최상 의 선택인지에 대해서는 많은 상충되는 관점들이 존재한다. 본 연구의 목적은 유한요소분석법을 사용하여 post-andcore system의 물리적인 성질이 치질의 응력분산에 미치는 영향을 분석하고 어떤 조합이 파절 저항에 도움이 되는지를 알아보는 것이다.

근관 치료된 상악 중절치를 삼차원 유한 요소법으로 Modeling하였다. $1.5 \mathrm{~mm}$ 의 ferrule 높이를 부여하고 외관은 zirconia ceramic crown으로 지정하였다. 세가지 평행한 형태의 포스트 (zirconia ceramic, glass fiber, and stainless steel)와 두 가지 코어 (Paracore and Tetric ceram) 물질을 6개의 모델로 조합하였다. 각각의 모델은 해면골, 피 질골, 치주인대, 그리고 $4 \mathrm{~mm}$ 근관 충전을 가지도록 설계하였다. $50 \mathrm{~N}$ 의 정적인 교합력이 치아 장축에서 60 도 각도로 치관의 설면에 적용시켰다. 모델들의 응력전달 특징의 차이를 분석하였고, 결과를 나타내는 데는 Maximum von Mises stress 값을 사용하였고 최대 변위량과 정수압도 계산하였다.

Glass fiber post로 수복된 경우 높은 탄성계수를 가진 레진 코어 모델 $(29.14 \mathrm{MPa})$ 에서 낮은 탄성계수의 코어 모델 (29.21 MPa)보다 더 낮은 응력이 발생하였다. Glass fiber post로 수복된 모델 $(0.03497-0.03499 \mathrm{~mm})$ 은 다른 포 스트로 수복된 모델들 $(0.03245-0.03452 \mathrm{~mm})$ 보다 더 많은 최대 변위량을 보였다. 이는 glass fiber post로 수복된 치아의 경우가 상대적으로 치아에 가해지는 힘에 의해 더 많이 움직였다는 것을 보여준다. Zirconia ceramic 이나 stainless steel 과 같이 탄성계수가 큰 포스트는 응력을 증가시키지만 포스트가 스트레스를 대부분 흡수하여 치질에는 스트레스가 낮게 나타났다. Glass fiber post로 수복된 모델에서는 코어와 크라운이 만나는 순면 치경부에서 가장 높은 응력이 발생하였다.

주요단어: 포스트, 삼차원 유한요소분석, Zirconia ceramic post, Glass fiber post 